IZA DP No. 7191

Self-Employment in China: Are Rural Migrant Workers and Urban Residents Alike?

Yuling Cui

Daehoon Nahm

Massimiliano Tani

January 2013 


\title{
Self-Employment in China: Are Rural Migrant Workers and Urban Residents Alike?
}

\author{
Yuling Cui \\ Macquarie University \\ Daehoon Nahm \\ Macquarie University \\ Massimiliano Tani \\ Macquarie University \\ and IZA
}

Discussion Paper No. 7191

January 2013

IZA

P.O. Box 7240

53072 Bonn

Germany

Phone: +49-228-3894-0

Fax: +49-228-3894-180

E-mail: iza@iza.org

Any opinions expressed here are those of the author(s) and not those of IZA. Research published in this series may include views on policy, but the institute itself takes no institutional policy positions. The IZA research network is committed to the IZA Guiding Principles of Research Integrity.

The Institute for the Study of Labor (IZA) in Bonn is a local and virtual international research center and a place of communication between science, politics and business. IZA is an independent nonprofit organization supported by Deutsche Post Foundation. The center is associated with the University of Bonn and offers a stimulating research environment through its international network, workshops and conferences, data service, project support, research visits and doctoral program. IZA engages in (i) original and internationally competitive research in all fields of labor economics, (ii) development of policy concepts, and (iii) dissemination of research results and concepts to the interested public.

IZA Discussion Papers often represent preliminary work and are circulated to encourage discussion. Citation of such a paper should account for its provisional character. A revised version may be available directly from the author. 


\section{ABSTRACT \\ Self-Employment in China: Are Rural Migrant Workers and Urban Residents Alike?}

This paper studies differences in the motivation to be self-employed between rural migrants and urban residents in modern China. Estimates of the wage differential between selfemployment and paid-employment obtained through a three-stage methodology using the 2002 China Household Income Project (CHIP), reveal that rural migrants become selfemployed to avoid low-pay city jobs, enhancing their odds of economic assimilation. Conversely, urban residents become entrepreneurs to move out of unemployment. The empirical analysis confirms that self-employment also attracts married individuals and those in good health, while it negatively relates to high educational attainment. The decomposition of hourly wage differences between pairs (by type of employment and residence status) shows that higher hourly wages of paid and self-employed urbanites over migrants predominantly arise through differences in coefficients (i.e. "discrimination") while those between self- and paid employment among urbanites are mostly due to differences in individual characteristics. Discrimination overwhelmingly accounts for hourly wage differences between self- and paid employment among rural immigrants. We interpret the relevant effect of discrimination in 2002 in urban labour markets as a sign of the institutional barriers associated with the Hukou system.

JEL Classification: $\quad \mathrm{C} 36, \mathrm{~J} 61, \mathrm{~J} 31, \mathrm{~J} 21, \mathrm{~J} 24$

Keywords: self-employment, wage differentials, rural migrant workers, urban residents

Corresponding author:

Massimiliano Tani

Department of Economics

Macquarie University

NSW 2109

Australia

E-mail: max.tani@mq.edu.au 


\section{Introduction}

Self-employment, as an effective form of entrepreneurship, is both risky and appealing as it generally offers business owners a sense of independence, confidence and life satisfaction. Entrepreneurs may not only circumvent or escape unemployment by running businesses for themselves, but also create more job opportunities for others, and increase labour demand. Entrepreneurship is of significant economic importance for growth, especially when it is associated with job creation.

Entrepreneurial activities in China have begun to become an important channel for employment in the 2000s after two decades of fast-pace economic growth and reform. According to data from the 2005 Chinese census, there were 64 million self-employed. Of these, about forty million were rural-urban migrants. The remaining 24 million were selfemployed urban residents. In that year self-employment accounted for about $25 \%$ of all rural migrants’ population and $10 \%$ of the urban labour force.

The higher incidence of self-employment amongst rural-urban migrants in China is prima facie puzzling, as they tend to receive lower average wages than self-employed urban residents and have almost as low hourly wages as migrant workers in paid-employment. Among the possible underlying reasons to explain the self-employment choice, research focused on Western countries suggest the possibility, over one's worklife, to attain higher earnings than in salaried work (Li, 1997; Li, 2000). Other motivations include avoiding unemployment (Thurik et al., 2008), or outright discrimination (Min, 1984). Research focused on China so far has explored the individual traits that underpin the choice of entrepreneurship (e.g. Meng, 2001; Giulietti et al., 2012; Zhang and Zhao, 2011). While existing work identifies important determinants of self-employment choice for rural migrants, little is known on what else, if anything, influences this choice once large differences in 
individual characteristics and, most importantly, working hours are controlled for (Borjas, 1990; Portes \& Zhou, 1996). Our paper aims to address this gap.

In particular, we study the choice to self-employment of migrants and urban residents taking into account their hours of work and other covariates, and decompose any remaining wage difference into individual observed characteristics ('endowment'), unexplained component ('coefficients' or 'discrimination'), and their interaction ('joint effects') using Blinder and Oaxaca's approach. We interpret differences in coefficients as predominantly stemming from the Household Registration System (Hukou system) ${ }^{1}$, which makes it almost impossible for people with rural hukou to access numerous types of urban jobs as well as urban welfare benefits (Cai, 2001). We carry out the empirical analysis using data from the China Household Income Project (CHIP), a nationally representative sample for the year of 2002, which covers a large set of variables reflecting the socioeconomic and demographic characteristics of both migrants and urbanites.

The results indicate large differences in log predicted wages between migrant and urban workers (both self- and paid-employed) associated with different coefficients, hence discrimination such as institutional barriers, rather than personal characteristics. Discrimination also affects the choice of rural migrants to become entrepreneurs vis-à-vis their salaried counterparts. Conversely, the main differences in log predicted wages between self-employed and salaried urbanites arise as a result of differences in observed individual characteristics, like human capital.

The paper is organized as follows. Section 2 reviews prior studies on selfemployment. Data and summary statistics are described in Section 3. Section 4 discusses the

\footnotetext{
${ }^{1}$ The Household Registration System (Hukou system) generally divides individuals into those who have ruralhukou if they live off agricultural production and their household registrations are in rural areas, and those who have urban-hukou if their food supplies are rationed by the state. Migrants from rural areas possess a ruralhukou.
} 
methodology for the analysis. Section 5 presents the empirical results. Final remarks conclude the paper in Section 6.

\section{Literature review}

The literature on self-employment suggests that this employment choice is a widely shared form of work for immigrants in most destination countries (e.g. Carr, 1996; Bernhardt, 1994; Andersson \& Wadensjo, 2004; Giulietti et al., 2012). In the standard model of labour market participation, migrants choose self-employment rationally to maximize their financial rewards. Empirical studies on the determinants of self-employment confirm this hypothesis. For example immigrants and native-born Canadians alike are attracted to self-employment due to its higher remuneration relative to paid-employment ( $\mathrm{Li}, 1997 ; \mathrm{Li}, 2000)$. A similar conclusion is also observed in U.K. by Rees and Shah (1986), which indicate the probability of self-employment depends positively on the earnings difference between self- and paidemployment. Constant and Zimmermann (2006) find that individuals are strongly pulled into self-employment if they expect higher earnings.

The main reason for higher financial returns in self-employment is normally attributed to human capital, which endows immigrants with skills and knowledge of organizing and operating businesses (Bates \& Dunham, 1993; Bates, 1994). Typically, once differences of human and financial capital between self- and paid-employment are controlled for, the advantage of immigrant entrepreneurs over their salaried counterparts tends to disappear. This outcome arises also when demographic characteristics are controlled for. For example Borjas (1990) shows that self-employed immigrants earn about 48\% more than their salaried counterparts, but this difference disappears after controlling for the large differences in age and gender between the two groups.

Similarly, Petersen (1989) and Portes and Zhou (1996) find that the higher earnings of immigrant entrepreneurs over salaried workers is largely explained by longer working hours: 
using samples of four entrepreneurial immigrants and control samples of black and white Americans in 1980, they show that the logarithm of hourly earnings gives a disadvantage to self-employed immigrants, but this is reversed when absolute monthly or weekly earnings are used. Chen et al. (2005), using non-parametric techniques, find that the kernel density of the wage differential is reduced when using hourly earnings compared to weekly earnings. These conclusions are however in disaccord with Hamilton (2000), who finds that the hourly earnings differentials do not have any influence on self-employment.

Self-employment may also provide an escape route to avoid unemployment, as suggested by Thurik et al. (2008) on a study of 23 OECD countries between 1974 and 2002 . They conclude that unemployment rates lead to start-up activities for self-employed individuals (the "refugee" effect) while high rates of self-employment can reduce unemployment in subsequent periods (the "entrepreneurial” effect). The "entrepreneurial” effect is found to be considerably stronger than the "refugee" effect, suggesting that entrepreneurship, especially if adequately supported in targeted policy measures, can abate unemployment. Less evidence exists on whether individuals with previous unemployment spells decide to become self-employed.

Along with unemployment, difficulties to access decent paid-employment and other forms of labour market discrimination seem to influence migrants to take up self-employment. For example, Min (1984) highlights that Korean immigrants’ perception of disadvantages in non-business occupations, their sense of 'status inconsistency' ${ }^{2}$, and their anticipation of economic mobility through business are three major factors which lead them to engaging in small business. Research on immigrant enclaves further suggests that growth in immigrant population and urban ethnic concentration can prompt the expansion of the immigrant enclave economy, which in turn offers a protected market for immigrant running small

\footnotetext{
${ }^{2}$ Status inconsistency refers to the situation in which two of the major status dimensions (race, education, occupation, and income) are unbalanced.
} 
businesses. Although most North American studies on immigrant self-employment suggest that labour market disadvantages and ethnic discrimination push migrants towards selfemployment, the contribution of discrimination to the propensity for self-employment is seldom quantified.

Studies focusing on Chinese migrant entrepreneurs, like the broader literature on selfemployment, mainly focus on exploring the effects of individual traits. Most studies find that formal education is negatively related to self-employment, and the higher is the educational level of the migrants, the lower is the probability of becoming self-employed. The strength of this relationship is substantial. Giulietti et al. (2012) show that college and above education reduces the likelihood of self-employment by $10.9 \%$. Similar findings are also observed in developed countries (e.g. Lofstrom, 2002). On the contrary, vocational training prior to migration and city work experience appear to have a positive influence on being entrepreneurs (Meng, 2001).

Additional determinants of entrepreneurship among immigrants in China include political party membership (e.g. Wu, 2002), and the existence of a strong family and social network (Zhang \& Zhao, 2011; Yueh, 2009). Despite the relatively high number of studies devoted to China's labour market, the choice of self-employment amongst migrants and urbanites remains relatively under-researched, particularly with reference to the sources of such a common choice: whether as a result of labour market discrimination or individual abilities. As in Giulietti et al. (2012), we contribute to this literature, with a focus on hourly wages as the main dependent variable and the identification of the sources of any emerging wage differentials using a tested methodology.

\section{Data and summary statistics}


The analysis is based on the 2002 wave of a large scale individual survey within the China Household Income Project (CHIP), which is conducted by the Institute of Economics, Chinese Academy of Social Sciences, with assistance from the Asian Development Bank and the Ford Foundation. ${ }^{3}$ CHIP 2002 includes a rural survey, an urban survey and a separate survey of rural-urban migrants. The rural-urban migration survey includes an additional subset of socio-economic and demographic variables to previous waves (i.e. CHIP 1995), such as occupation types, unemployment duration, welfare benefits, and family financial situation before leaving the home village. Overall, the migrant dataset includes 76 variables and 5,327 persons, while the urban dataset covers 151 variables and 20,632 individuals. A self-employed worker denotes an owner (manager) of private or self-employed enterprises, while a paid-employed worker is one who mainly engages in wage/salary jobs. The latter includes professionals or technicians, managers of enterprise or institution, clerical staff, and workers from manufacturing, commerce, domestic service, service, construction, and other sectors. Individuals aged over 15 years who work either as self-employed or in paid jobs are included in the analysis.

Table 1 reports the proportions of the self-employed out of rural labour, rural migrant workers, permanent migrants and urbanites. Note that rural labour refers to those who live in rural areas, have rural-hukou, and engage in non-agricultural jobs, while permanent migrants denote rural migrants who have owned an urban-hukou since 1978. The proportion of rural migrants who engage in self-employed activities is much larger than the proportions in the other groups: over 52\% rural migrants are self-employed (a much higher proportion than the 2005 Census) while only 5\% urban residents are entrepreneurs.

The main reasons for such high percentages are shown in Table 2, which reports the distribution of answers to the corresponding survey questions. The low income received from

\footnotetext{
${ }^{3}$ CHIP data is a cross-section data surveyed from 1988 to 2007 . However, rural-urban migrant samples are not collected in CHIP 1988 and the latest dataset 2007 has not been publicly available.
} 
paid-employment forms the first primary reason, representing as large as $43 \%$ migrants, which is followed by entrepreneurial willingness and unstable jobs in paid-employment with a total proportion of $38 \%$. Being entrepreneurs gives most rural migrants an expectation of higher incomes and more stable jobs than what available as a salaried worker. For selfemployed urban residents, nearly $46 \%$ of them are self-employed as a result of a prior dismissal.

Table 3 provides the summary statistics. Migrant entrepreneurs are typically younger (35 vs. 40 years old) and healthier (92\% vs. 71\%) than the corresponding urban residents. Self-employed generally have a lower educational level than paid workers. About $46 \%$ of self-employed urbanites have senior and above educational levels, as compared to $76 \%$ of their counterparts in paid-employment. For rural migrants with the same levels of education, the corresponding percentages are $15 \%$ and $22 \%$. When measured in average hourly wages, self-employed migrants earn a little more than migrants in a paid work (2.9 vs. 2.5 yuan), while salaried urbanites earn twice (6 yuan) as much as the entrepreneurs. Benefits as nonpecuniary income are also reported, as a small percentage $(<4 \%)$ of self-employed migrants are covered by benefits of pension, medical care, and unemployment. In contrast, more than 90\% urban self-employed enjoy medical care which, however, is mostly purchased privately rather than through State or employer medical and health services.

The industrial distribution by self-employment status highlights that about $65 \%$ of the migrant and 52\% of the urban self-employed engage in wholesale/retail/food services (WRF). Most entrepreneurs therefore run businesses offering daily necessaries and catering to consumers in the urban labour market. The hourly wage differences by industry (Table 4) shows that WRF migrant and urban entrepreneurs have the lowest wage levels: about 2.5 yuan and 3 yuan. Instead, this is perhaps due to the low operation cost and basic strategy of the business survival and development in urban areas. 
Regional average wages (Table 5) indicate that rural migrants obtain low wages compared to urban residents in most regions, but those who are self-employed receive relatively high hourly wages in the coastal region and metropolitan cities: 6 yuan in Jiangsu, followed by Beijing (3.9 yuan) and Guangdong (3.6 yuan). To illustrate the distribution of wages by residence status, Figure 1 plots the hourly wage distributions of each group disaggregated also by type of employment. The distributions appear "normal” and depict smaller wage dispersions for rural migrants than for urban residents. Taking the wage distribution of self-employed urbanites as a benchmark, those of self-employed and paidwork migrants fall disproportionately on the lower-than-medium part of the benchmark distribution, while this is just the opposite for paid urbanites. There seems a clear raking in average pay and wage dispersion with urbanites' salaried work at the top and migrants' salaried work at the bottom of the scale.

\section{Methodology}

The methodological framework is a three-stage process previously used in selfselection models of self-employment (e.g. Taylor, 1996; Rees \& Shah, 1986; Constant \& Zimmermann, 2006). We assume that there are only two main occupational statuses available in the labour market: self-employment and paid-employment. An individual's underlying decisional process is essentially based on comparing the utilities of the two occupational statuses. As in Castellano et al. (2010), an individual worker becomes self-employed when the relative wage is higher than in paid-employment, $\ln \hat{y}_{s i}>\ln \hat{y}_{p i}$, ceteris paribus. To obtain the expected wage differential between the two employment outcomes, individuals' expected earnings of self-employment and paid-employment are separately derived from 
wage equations. However, estimating the parameters in the wage equations by OLS may lead to a selection bias, as the distribution of the error term in each equation is truncated. ${ }^{4}$

We address this possible issue by including a selectivity term, $\lambda_{j i}(j=s$ or $p$ ), estimated using a reduced-form probit model defined by (with the subscript $s$ and $p$ omitted for simplicity):

$$
I_{i}^{*}=W_{i}^{\prime} \delta_{i}+\omega_{i}
$$

where, $I_{i}^{*}$ is an unobservable continuous variable (i.e. latent variable), which expresses the relative advantage of self-employment as the difference between the utilities linked to the two statuses. The vector $W$ is the complete set of instruments, including all exogenous and predetermined variables of the wage equations and the probit model.

We then perform wage regressions including the selectivity term $-\lambda_{j i}$ estimated from the reduced-form probit model to obtain unbiased estimates of expected earnings in each state. The conditional expectations of the logs of earnings are given by:

$$
\begin{aligned}
& E\left(\ln w_{s i} \mid I_{i}^{*}>0\right)=X_{i}^{\prime} \beta_{s}+\sigma_{s \varepsilon} \lambda_{s i} \\
& E\left(\ln w_{p i} \mid I_{i}^{*} \leq 0\right)=X_{i}^{\prime} \beta_{p}+\sigma_{p \varepsilon} \lambda_{p i}
\end{aligned}
$$

where $\lambda_{s i}=\frac{\phi\left(W_{i}^{\prime} \gamma\right)}{\Phi\left(W_{i}^{\prime} \gamma\right)}$ and $\lambda_{p i}=-\frac{\phi\left(W_{i}^{\prime} \gamma\right)}{1-\Phi\left(W_{i}^{\prime} \gamma\right)}$ are the Heckman's lambdas when assuming that the error terms follow a normal distribution, that is, $\mu_{s i} \sim N\left(0, \sigma_{s}^{2}\right)$ and $\mu_{p i} \sim N\left(0, \sigma_{p}^{2}\right)$. The

\footnotetext{
${ }^{4}$ The wage equations estimated by the OLS method are shown as follows:

$$
\begin{array}{lll}
\ln w_{s i}=X_{s i}^{\prime} \beta_{s}+\mu_{s i} & \text { if } \quad I_{i}^{*}>0 \\
\ln w_{p i}=X_{p i}^{\prime} \beta_{p}+\mu_{p i} & \text { if } \quad I_{i}^{*} \leq 0
\end{array}
$$
}

where, the vectors $X_{s i}$ and $X_{p i}$ refer to the explanatory variables that affect earnings of self-employment and paid-employment, respectively. $\beta_{s}$ and $\beta_{p}$ are the corresponding coefficient vectors. $I_{i}^{*}$ is a latent variable which expresses the relative advantage to self-employment as the difference between the utilities linked to the two status. The biased estimates of the wages result from the fact that the individuals' wages in their particular employment states are only observed. This causes the error terms $\mu_{s i}$ and $\mu_{p i}$ to have a truncated distribution: $E\left(\mu_{s i} \mid I_{i}^{*}>0\right) \neq 0$ and $E\left(\mu_{p i} \mid I_{i}^{*} \leq 0\right) \neq 0$. 
function $\phi\left(W_{i}^{\prime} \gamma\right)$ is the standard normal probability density function (PDF) and $\Phi\left(W_{i}^{\prime} \gamma\right)$ is the cumulative distribution function (CDF).

The parameters $\sigma_{s \varepsilon}$ and $\sigma_{p \varepsilon}$ represent the covariance between the error terms of the latent variable $I_{i}^{*}$ and the wage equations. Since the variables affecting earnings for selfemployment and salaried work are the same, the subscript $s$ and $p$ in $X$ are omitted in Equations (2) and (3). A statistically significant $\sigma_{s \varepsilon}$ in the self-employed wage equation indicates that self-employed individuals are not a random but a self-selected sample. The predicted earnings for each type of employment are used to estimate the expected wage differential, which enters as a regressor in the estimation of the probability of selfemployment.

The final stage is to estimate the structural probit using the difference in predicted wages. While this model is similar to the reduced-form probit model, the key identifying variable is the expected wage differential between self-employment and paid-employment.

$$
I_{i}^{*}=U_{s i}+\delta_{s i}-U_{p i}-\delta_{p i}=\alpha\left(\ln \widehat{w}_{s i}-\ln \widehat{w}_{p i}\right)+Z_{i}^{\prime} \gamma+\varepsilon_{i} \quad y_{i}= \begin{cases}1 & \text { if } I_{i}^{*}>0 \\ 0 & \text { if } I_{i}^{*} \leq 0\end{cases}
$$

where the latent variable $I_{i}^{*}$, which can take on any value in the real line and generate the observed binary $y_{i}$ (i.e. a manifest variable which is coded 1 if the worker is self-employed and 0 if paid-employed), is supposed to be linearly related to the wage differential between self- and paid-employment and a set of other observed characteristics (Lee, 1978; Parker, 2004). An individual chooses to be self-employed if $I_{i}^{*}>0$.

The parameter $\alpha$ is a scalar, expected to be positive, related to the expected wage differential between the two employment outcomes. The parameter $Z_{i}$ denotes a set of explanatory variables that can affect choice and $\gamma$ is a vector of coefficients. The variables $\ln \widehat{w}_{s i}$ and $\ln \widehat{w}_{p i}$ represent the logs of expected earnings of self-employed and salaried workers with the 
same characteristics, respectively. Random errors are assumed to follow the standardised distribution, that is, $\varepsilon_{i} \sim N(0,1)$.

Other control variables include health (healthy=1), ethnicity (ethnic minority=1), political status (members of Communist Party of China=1), marital status (married=1), education, vocational training, household size, industry and regional dummies. These are included in both the probit and wage equations. To reflect the flexibility in the number of working hours for the self-employed and to identify the unbiased expected wage in each state, working hours per month are included in both reduced-form and structural probit, while they are not excluded from the wage equations.

Unemployment spells prior to taking up self-employment enters the probit equations but not the wage equations. The present model specifically includes unemployment duration and experience. The former is formalised by the CHIP survey question on tenure to find a new job with equivalent pay if migrants were unemployed, and the latter refers to the question on whether urban residents had unemployment experience at the end of 2002. The unemployment duration taken as a continuous variable in our estimation is more robust to measurement error than a discrete variable. It has values of one week, two weeks, one month, two months, and six month and above. We expect that having experienced unemployment is a positive determinant of subsequent self-employment.

Assets and occupation before migration are available only in the rural-urban migration dataset, and hence included exclusively in the probit models. Asset is defined by money brought from family, which may include funds used or available for the establishment of a business. We expect that the more money brought from family, the higher the probability of rural migrants’ being entrepreneurs (Evans \& Jovanovic, 1989). 
Occupation before migration reflects an individual's background in the village of origin, and is represented by two dummy variables: (i) employment in township and village enterprises (TVEs) and non-agricultural self-employment; and (ii) educational attainment at the level of graduates (or non-graduates) or 'village cadre/teacher/other'. The reference group is represented by rural migrants working in agriculture. City work experience is a continuous variable, measured by years of work at the end of 2002, but only in the current state of employment. This makes this variable irrelevant for the probit model of self-employment and hence we include it only in the wage equations and thus in the reduced-form probit model. We add a square term as the effects of work experience may not be linear (Hamilton, 2000).

To investigate whether the wage differential is mainly determined by observable personal characteristics (“endowment”) or is a consequence of unobserved endowment and institutional barriers, the counterfactual decomposition approach of Blinder-Oaxaca (Blinder, 1973; Oaxaca, 1973) is applied. Its aim is to detect how much of the wage differential between four pairs defined by residence and employment status can be explained by (1) the endowment effect (i.e. individual characteristics), (2) the difference in coefficients, which is often used as a measure for discrimination and captures all potential effects of other unobserved factors, and (3) the interaction term, which is interpreted as the simultaneous effect of endowment and discrimination. The decomposition is formulated from the viewpoint of paid-employment and rural migrants, respectively, and is written as:

$$
\hat{R}=\overline{\ln y_{s}}-\overline{\ln y_{p}}=\left(\bar{X}_{s}-\bar{X}_{p}\right)^{\prime} \hat{\beta}_{p}+\bar{X}_{p}^{\prime}\left(\hat{\beta}_{s}-\hat{\beta}_{p}\right)+\left(\bar{X}_{s}-\bar{X}_{p}\right)^{\prime}\left(\hat{\beta}_{s}-\hat{\beta}_{p}\right)
$$

where $\left(\bar{X}_{s}-\bar{X}_{p}\right)^{\prime} \hat{\beta}_{p}$ is the "explained" part of the outcome differential that is attributable to individual endowment differences (e.g. different levels of human capital and other personal characteristics), and $\bar{X}_{p}^{\prime}\left(\hat{\beta}_{s}-\hat{\beta}_{p}\right)$ measures the contribution of differences in the coefficients, including differences in the intercept (e.g. the effect attributable to 
institutional settings like barriers to access certain parts of the labour market, and/or other features of the labour market like segmentation or outright discrimination). The interaction element $\left(\bar{X}_{s}-\bar{X}_{p}\right)^{\prime}\left(\hat{\beta}_{s}-\hat{\beta}_{p}\right)$ measures the simultaneous effect of differences in endowments and coefficients. $\bar{X}_{n}(n=s$ or $p)$ is a vector containing a set of predictors and a constant. $\hat{\beta}_{n}(n=s$ or $p)$ contains the coefficient estimates.

\section{Empirical Results}

The wage regressions for self-employed and salaried rural migrants show that returns to education are positive and significant (Table 6). The higher the education level, the higher the wage rate, ceteris paribus. However, there is no such a statistically significant relationship for urban residents (Table 7) with the exception of paid-employed urban residents for whom the higher is the level of education, the higher is their wage rate. Vocational training has a stronger positive influence on the earnings of the urban selfemployed than on migrant entrepreneurs: one additional month of vocational training increases hourly wages by $4.5 \%$ for the urban self-employed and by $1.6 \%$ for migrant entrepreneurs. Vocational training currently provided appears to have limited relevance for migrant entrepreneurs, perhaps due to the requirements of their sector of activity.

Rural migrants who are self-employed can attain the highest wages when engaging in manufacturing and construction, while urban residents earn the highest wages by working in WRF. Though migrant entrepreneurs obtain lower hourly wages in WRF, their probability of joining this industry is not lower than entering other sectors, suggesting that opening up a retail activity like a shop or restaurant may actually be an effective way to enhance their economic assimilation. Despite significant wage differences between migrant and urban selfemployed and paid-employed, the wage gap is reduced when rural migrants become 
entrepreneurs: by about $9 \%$ on average vis-à-vis self-employed and 6\% versus paidemployed urbanites, respectively.

The estimation results of the structural probit model are presented in Table 8. The positive and significant effect of hourly wage differential reflects that the probability of being self-employed increases as expected self-employed earnings increase as entrepreneurship becomes more profitable vis-à-vis salaried work. A similar finding is obtained by Giulietti et al. (2012), though the size of the effect found here is larger. For urban residents, the coefficient for wage differential is not statistically significant, though the sign of estimated coefficient is positive. Experiencing unemployment increases the probability of selfemployment by nearly $1.2 \%$ for an urban resident, confirming that urbanites, too, are sensitive to job security (Akewushola et al., 2007; Thurik et al., 2008; Taylor, 1996).

The independence and freedom offered by self-employment are clearly attractive job attributes, as they significantly increase the probability of self-employment. Longer working hours probably lead to higher wages, and accordingly motivate entrepreneurship. Education plays little or negative role in the decision of being self-employed: it has no significant influence for rural migrants and a negative effect on urban residents. This is consistent with the findings of Van der Sluis et al. (2005) and Bates (1999), suggesting that the more educated tend to prefer engaging in low risk and demanding wage/salary jobs.

Married individuals are more likely to enter self-employment, possibly because they can count on a second source of income from their partners (Mohapatra et al., 2007; Gagnon et al., 2009). Good health is also important for self-employment, implying that this employment choice is not a 'refuge' for those affected by physical disabilities, old age, and low personal productivity (Rees and Shah, 1986; Zissimopoulos and Karoly, 2007). Longer working hours and greater responsibility are likely to require healthier individuals to work in 
such a demanding status (e.g. Quinn, 1980). Rural migrants also have a lower inclination to join other industries than WRF, perhaps because of monetary and other barriers to entry.

With reference to the financial source of starting up a business, Table 8 reports that the more money is brought from family, the higher is the probability of migrants being entrepreneurs. The data confirm that the amount of money invested by self-employed migrants is mainly from family savings and borrowings from relatives and friends, accounting for nearly 95\% of capital (see Table 3). Only a small percentage of the amount is borrowed from non-bank loans and others. This seems to indicate the presence of constraints in accessing credit through formal channels, and emphasizes the significant role of family and relatives in supporting the start-up of businesses. The regional dummy variable shows that urban residents prefer self-employment but only in the coastal region, that is, Guangdong, while migrant entrepreneurs are mainly clustered into the interior regions of Anhui, Henna, and Sichuan. This may reflect migrants' broad social-family networks in the home region.

To test whether the underlying drivers of being entrepreneurs between rural migrants and urban residents are alike, the structural probit model is re-estimated using a combined sample where $D$ (as a dummy variable) distinguished rural migrants $(D=1)$ from urban residents $(D=0)$. The coefficients for the interactions with the dummy $(X D)$, reported in the last column of Table 8, highlight the presence of different determinants in the choice of selfemployment between rural migrants and urban residents. As indicated, the coefficients for the interactions with wage differentials, vocational training, ethnicity, education, and the manufacturing and construction industry dummy are all statistically significantly different from zero. The likelihood-ratio (LR) tests for sub-groups of the coefficients are carried out and their results are reported in Table 9. The effects of the regional dummy variables are not significantly different between migrant and urban groups when the individual effects are considered separately. However, the effects are significantly different between the two 
groups when they are jointly considered, as shown by the highly significant likelihood ratio statistic (Chi2: 29.2). The effects of education also differ, as the null hypothesis of equal coefficients is strongly rejected (p-value: $0.08 \%$ ). The effects of the industry-dummy variables are also significantly different (p-value: $0.02 \%)$.

Table 10 reports the decompositions of wage differential between the four pairs of groups. It presents the mean predictions of the log wage for the two employment statuses, the total difference in the predicted mean log wage between the two statuses, and its decomposition. The total wage difference between paid-employed urbanites and migrants is much higher than the difference between any other pairs. The mean of logarithm is 1.5556 for paid-employed urbanites and 0.6909 for paid-employed migrants, yielding a log-wage gap of 0.8647. This is mainly due to coefficient differences, which account for about $43 \%$ of the gap, and quantifies the change in paid-employed migrants' log wage when the paid-employed urbanites' coefficients are applied to the paid migrants' characteristics. It also suggests that paid urbanites may have unobserved desirable characteristics, such as familiarity with the urban labour market or an easier access to jobs than salaried migrants.

Self-employed migrants have higher wage levels than salaried workers (0.77645 vs. 0.6909). Here the wage difference is mainly attributed to differences in the coefficients (e.g. Min, 1984; Li, 1993). We attribute to discrimination the main reason for the incentives for migrants to become self-employed. The interaction term also accounts for a large proportion of the difference (around 28\%), highlighting a substantial simultaneous effect of differences in endowments and unexplained component.

Paid-employed urbanites have higher wages than self-employed urbanites, with a total difference of 0.5640 , accounted for mostly by the endowment difference (64\%). The negative sign suggests that salaried workers would receive lower hourly wages if they had the same 
characteristics than the self-employed. Salaried urbanites therefore seem to have better attributes, like human and social capital than, their self-employed counterparts.

Overall, the decomposition output shows that the largest wage differentials occur between paid urbanites and migrants, while the smallest arise between self-employed and salaried migrants. As shown, the hourly wage gap is largely due to discrimination against migrant workers. Such discrimination may actually act as a catalyst to prompt many rural migrants to choose self-employment in order to avoid too low hourly wages offered by salaried work.

\section{Conclusions and implications}

Migrants and urbanites have different motives to enter into self-employment: the former do it to enhance their financial returns and avoid the discrimination faced in the urban labour market; the latter to escape from unemployment. Being entrepreneur reduces the wage gaps between migrants and urbanites, offering a channel to better assimilate economically into urban areas. Despite the progressive reduction of barriers to the internal movement of workers and the increasing policy protection benefiting rural migrants, our results suggest that existing institutional barriers, such as the hukou system, still affects rural migrants' earnings. We also find that a previous experience of unemployment motivates urbanites to become entrepreneurs. Though self-employment emerges as a channel, and a likely harsh one, to escape unemployment, targeted policies to train and encourage self-employment may contribute to a better functioning of China’s urban labour markets. 


\section{Reference}

Akewushola, R. O., Olateju, O. I. \& Adeyemi, O. T. 2007. Poverty, unemployment and growth in Nigeria: The role of entrepreneurship. Available: http://lexetscientia.univnt.ro/.

Andersson, P. \& Wadensjo, E. 2004. Self-employed immigrants in Denmark and Sweden: A way to economic self-reliance? IZA Discussion Paper No. 1130. Bonn.

Audretsch, D. B. \& Thurik, A. R. 2001. What's new about the new economy? Sources of growth in the managed and entrepreneurial economies. Industrial and Corporate Change, 10, 267-315.

Bates, T. 1994. Social resources generated by group support networks may not be beneficial to Asian immigrant-owned small businesses. Social Forces, 72, 671-689.

Bates, T. 1999. Existing self-employment: An analysis of Asian immigrant-owned small businesses. Small Business Economics, 13, 171-183.

Bates, T. \& Dunham, C. R. 1993. Asian-American success in self-employment. Economic Development Quarterly, 7, 199-214.

Bernhardt, I. 1994. Comparative advantage in self-employment and paid work. The Canadian Journal of Economics / Revue canadienne d'Economique, 27, 273-289.

Blinder, A. S. 1973. Wage discrimination: Reduced form and structural estimates. The Journal of Human Resources, 8, 436-455.

Borjas, G. J. 1986. The self-employment experience of immigrants. The Journal of Human Resources, 21, 485506.

Borjas, G. J. 1990. Friends or strangers: The impact of immigrants on the US economy, Basic Books New York.

Cai, F. 2001. Institutional barriers in two processes of rural Labour migration in China. Working Paper Series No. 9. Beijing: Institute of Population Studies, Chinese Academy of Social Sciences.

Carr, D. 1996. Two paths to self-employment? Women's and men's self-employment in the United States, 1980 Work and Occupations, 23, 26-53.

Castellano, R., Quintano, C. \& Punzo, G. 2010. A mobility analysis across European countries with a threestage structural probit model. Dynamics of Social and Economic Systems. Benevento, Italy: http://www.dyses2010.unisannio.it.

Chen, Y., Démurger, S. \& Fournier, M. 2005. Earnings differentials and ownership structure in Chinese enterprises. Economic Development and Cultural Change, 53, 933-958.

Constant, A. \& Zimmermann, K. F. 2006. The making of entrepreneurs in Germany: Are native men and immigrants alike? Small Business Economics, 26, 279-300.

Evans, D. S. \& Jovanovic, B. 1989. An estimated model of entrepreneurial choice under liquidity constraints. Journal of Political Economy, 97, 808-827.

Gagnon, J., Xenogiani, T. \& Xing, C. 2009. Are all migrants really worse off in urban labour markets? New empirical evidence from China. IARIW-SAIM Conference Working paper 278.

Giulietti, C., Ning, G. \& Zimmermann, F. K. 2012. Self-employment of rural-to-urban migrants in China. International Journal of Manpower, 33, 96-117.

Hamilton, B. 2000. Does entrepreneurship pay? An empirical analysis of the returns to self-employment. Journal of Political Economy, 108, 604-631. 
Lee, L.-F. 1978. Unionism and wage rates: A simultaneous equations model with qualitative and limited dependent variables. International Economic Review, 19, 415-433.

Li, P. S. 1993. Chinese investment and business in Canada: Ethnic entrepreneurship reconsidered. Pacific Affairs, 66, 219-243.

Li, P. S. 1997. Self-employment among visible minority immigrants, white immigrants, and native-born persons in secondary and tertiary industries of Canada. Canadian Journal of Regional Science, 20, 103-118.

Li, P. S. 2000. Economic returns of immigrants' self-employment. The Canadian Journal of Sociology / Cahiers canadiens de sociologie, 25, 1-34.

Li, P. S. 2001. Immigrants' propensity to self-employment: Evidence from Canada. International Migration Review, 35, 1106-1128.

Lofstrom, M. 2002. Labour market assimilation and the self-employment decision of immigrant entrepreneurs. Journal of Population Economics, 15, 83-114.

Meng, X. 2001. The informal sector and rural-urban migration-A Chinese case study. Asian Economic Journal, $15,71-89$.

Min, P. G. 1984. From white-collar occupations to small business: Korean immigrants' occupational adjustment. The Sociological Quarterly, 25, 333-352.

Mohapatra, S., Rozelle, S. \& Goodhue, R. 2007. The rise of self-employment in rural China: Development or distress? World Development, 35, 163-181.

Oaxaca, R. 1973. Male-female wage differentials in urban labour markets. International Economic Review, 14, 693-709.

Parker, S. C. 2004. The economics of self-employment and entrepreneurship, Cambridge University Press.

Petersen, T. 1989. The earnings function in sociological studies of earnings inequality: Functional form and hours worked. Research in Social Stratification and Mobility, 8, 221-250.

Portes, A. \& Zhou, M. 1996. Self-employment and the earnings of immigrants. American Sociological Review, $61,219-230$

Quinn, J. F. 1980. Labour-force participation patterns of older self-employed workers. Social Security Bulletin, 43, 17-28.

Rees, H. \& Shah, A. 1986. An empirical analysis of self-employment in the U.K. Journal of Applied Econometrics, 1, 95-108.

Solinger, D. J. 1999. Contesting citizenship in urban China: Peasant migrants, the state, and the logic of the market, Berkeley: University of California Press.

Taylor, M. P. 1996. Earnings, independence or unemployment: Why become self-employed? Oxford Bulletin of Economics and Statistics, 58, 253-266.

Thurik, A. R., Carree, M. A., Van Stel, A. \& Audretsch, D. B. 2008. Does self-employment reduce unemployment? Journal of Business Venturing, 23, 673-686.

Van Der Sluis, J., Van Praag, M. \& Vijverberg, W. 2005. Entrepreneurship selection and performance: A metaanalysis of the impact of education in developing economies. The World Bank Economic Review, 19, 225-261.

Wu, X. 2002. Embracing the market: Entry into self-employment in transitional China, 1978-1996. Population Studies Centre (University of Michigan), Working Paper No. 512. 
Yueh, L. 2009. Self-employment in urban China: Networking in a transition economy. China Economic Review, 20, 471-484.

Zhang, J. \& Zhao, Z. 2011. Social-family network and self-employment: Evidence from temporary rural-urban migrants. IZA Discussion Paper No. 5446. Bonn.

Zissimopoulos, J. M. \& Karoly, L. A. 2007. Transitions to self-employment at older ages: The role of wealth, health, health insurance and other factors. Labour Economics, 14, 269-295. 
Table 1. The proportions of the self-employed by different groups in 2002

\begin{tabular}{ccccc}
\hline & Rural labour & Rural migrants & Permanent migrants & Urbanites \\
\hline Self-employment (\%) & 12.09 & 52.38 & 4.71 & 4.31 \\
Paid-employment (\%) & 87.91 & 47.62 & 95.29 & 95.69 \\
Observations & 9,282 & 3,408 & 2,401 & 9,949 \\
& $(100)$ & $(100)$ & $(100)$ & $(100)$ \\
\hline
\end{tabular}

Table 2. Selected characteristics of the self-employed for the rural migrant and urbanite groups

\begin{tabular}{|c|c|c|}
\hline & Rural migrants & Urbanites \\
\hline \multicolumn{3}{|l|}{ Had you ever changed work units before being self-employed? } \\
\hline 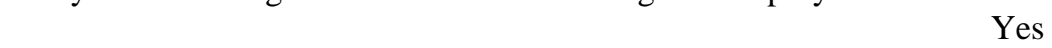 & 33.5 & 15.22 \\
\hline If yes, how many & 1.0 & 2.0 \\
\hline No & 66.5 & 84.78 \\
\hline \multicolumn{3}{|l|}{ What was the main reason for leaving your previous job? } \\
\hline 1) low income & 43.37 & 14.71 \\
\hline 2) the job was not stable & 10.68 & 4.41 \\
\hline 3) working conditions were poor & 6.63 & 2.94 \\
\hline 4) benefits and social securities were not good & 0.16 & 1.47 \\
\hline 5) contract expired & 1.62 & 2.94 \\
\hline 6) dismissed ${ }^{\mathrm{a}}$ & 1.94 & 45.59 \\
\hline 7) wanted to start your own business & 23.95 & 16.18 \\
\hline 8) increased family burden & 0.97 & l \\
\hline 9) other (including job transfer) & 10.68 & 11.76 \\
\hline \multicolumn{3}{|l|}{$\begin{array}{l}\text { Have you ever thought about moving to a better work unit if you are self- } \\
\text { employed? }\end{array}$} \\
\hline 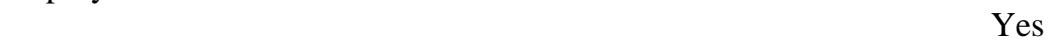 & 31.93 & 34.55 \\
\hline 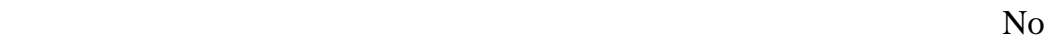 & 68.07 & 65.45 \\
\hline \multicolumn{3}{|l|}{ If yes, what was the main reason for leaving self-employment? } \\
\hline 1) To get better pay & 79.01 & 43.51 \\
\hline 2) To get a more stable job & 8.49 & 28.24 \\
\hline 3) To have better working conditions & 3.30 & 9.92 \\
\hline 4) To have better benefits and social securities & 2.36 & 12.98 \\
\hline 5) To have housing & 0.71 & 3.05 \\
\hline 6) To start your own business & 2.36 & 0.76 \\
\hline 7) Other & 3.77 & 1.53 \\
\hline Number of Obs. & 1,769 & 385 \\
\hline
\end{tabular}

Notes: The dismissed ${ }^{\mathrm{a}}$ for urbanites includes the lay off by the bankruptcy of work units. 
Table 3. Summary statistics of rural migrant workers and urbanites in 2002

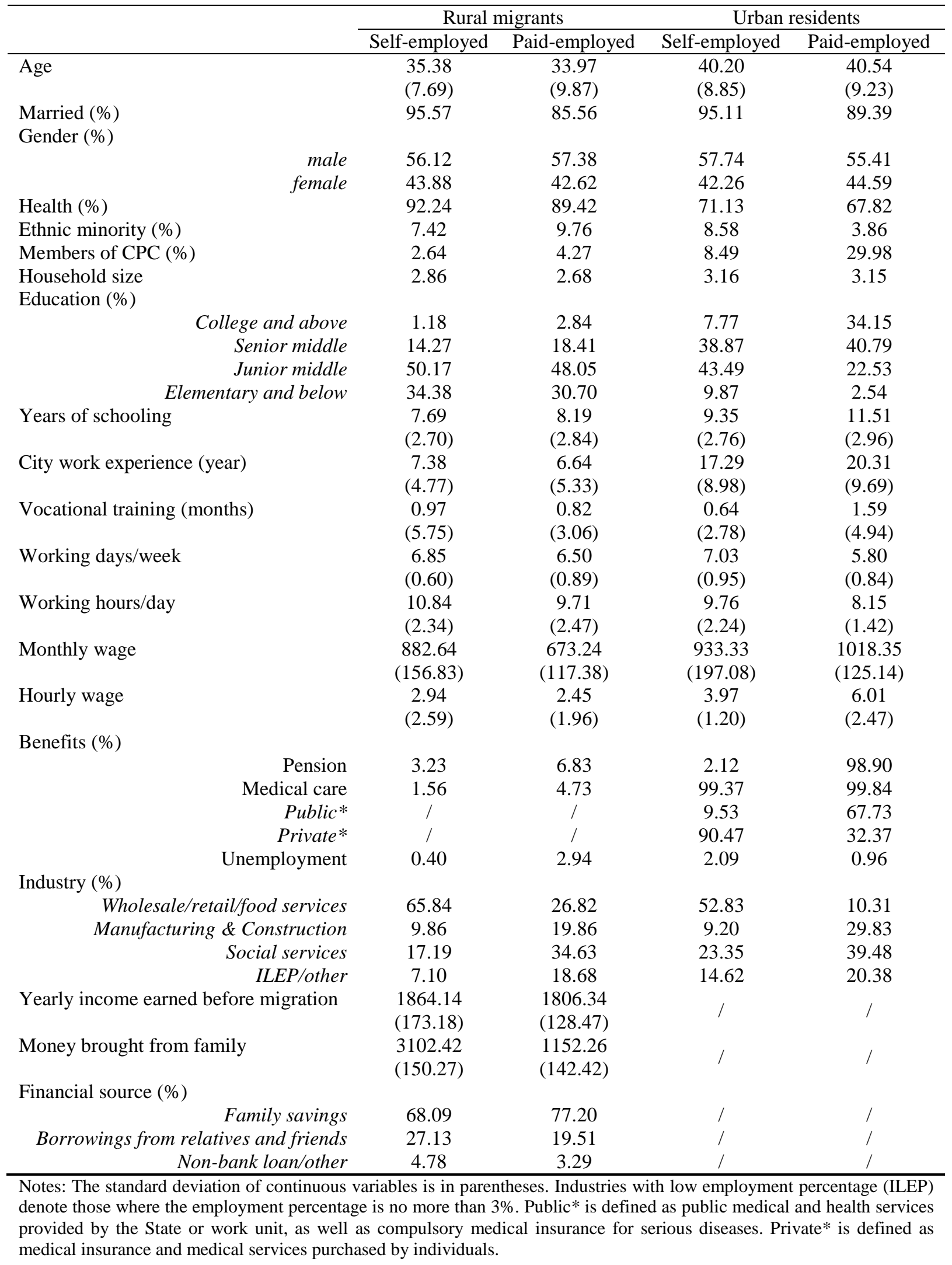


Table 4. Hourly wages by industry for self-employment status

\begin{tabular}{lcccccc}
\hline & \multicolumn{2}{c}{ Rural migrants } & \multicolumn{3}{c}{ Urban residents } \\
\cline { 2 - 7 } & $\begin{array}{c}\text { Self- } \\
\text { employed }\end{array}$ & $\begin{array}{c}\text { Paid- } \\
\text { employed }\end{array}$ & Ws-Wp & $\begin{array}{c}\text { Self- } \\
\text { employed }\end{array}$ & $\begin{array}{c}\text { Paid- } \\
\text { employed }\end{array}$ & Ws-Wp \\
\hline Manufacturing \& Construction & 5.04 & 3.12 & 1.92 & 5.98 & 5.12 & 0.86 \\
ILEP/Other & 4.38 & 2.54 & 1.84 & 6.05 & 6.48 & -0.43 \\
Wholesale/ retail/food services & 2.53 & 2.21 & 0.32 & 3.13 & 4.52 & -1.39 \\
Social service & 2.50 & 2.23 & 0.27 & 3.44 & 6.94 & -3.50 \\
\hline
\end{tabular}

Notes: Ws and Wp denotes the self-employed wages and paid-employed wages, respectively.

Table 5. Hourly wages for self-employment by regions

\begin{tabular}{|c|c|c|c|c|c|c|}
\hline & \multicolumn{3}{|c|}{ Rural migrants } & \multicolumn{3}{|c|}{ Urban residents } \\
\hline & $\begin{array}{c}\text { Self- } \\
\text { employed }\end{array}$ & $\begin{array}{c}\text { Paid- } \\
\text { employed }\end{array}$ & $\begin{array}{c}\text { Wage } \\
\text { differentials }\end{array}$ & $\begin{array}{c}\text { Self- } \\
\text { employed }\end{array}$ & $\begin{array}{c}\text { Paid- } \\
\text { employed }\end{array}$ & $\begin{array}{c}\text { Wage } \\
\text { differentials }\end{array}$ \\
\hline \multicolumn{7}{|l|}{ Metropolitan city: } \\
\hline Beijing & 3.93 & 3.22 & 0.71 & 14.43 & 9.27 & 5.16 \\
\hline \multicolumn{7}{|l|}{ Coastal region: } \\
\hline Liaoning & 3.25 & 2.41 & 0.84 & 3.51 & 5.25 & -1.74 \\
\hline Jiangsu & 5.53 & 2.73 & 2.80 & 4.08 & 6.11 & -2.03 \\
\hline Guangdong & 3.61 & 3.11 & 0.50 & 6.21 & 9.50 & -3.29 \\
\hline \multicolumn{7}{|l|}{ Interior region: } \\
\hline Shanxi & 2.55 & 2.22 & 0.33 & 3.49 & 4.78 & -1.29 \\
\hline Anhui & 2.10 & 2.28 & -0.18 & 3.45 & 5.34 & -1.89 \\
\hline Henan & 2.68 & 2.02 & 0.66 & 4.50 & 4.28 & 0.22 \\
\hline Hubei & 2.68 & 2.36 & 0.32 & 2.72 & 5.38 & -2.66 \\
\hline Sichuan & 2.12 & 2.28 & -0.16 & 2.17 & 4.77 & -2.60 \\
\hline Yunnan & 2.84 & 2.25 & 0.59 & 3.15 & 5.98 & -2.83 \\
\hline Gansu & 2.82 & 1.71 & 1.11 & 2.59 & 4.84 & -2.25 \\
\hline
\end{tabular}

Note: Wage differentials are the substitution between wage for self-employment and wage for paid-employment.

Figure 1 Distribution for rural migrants and urban residents

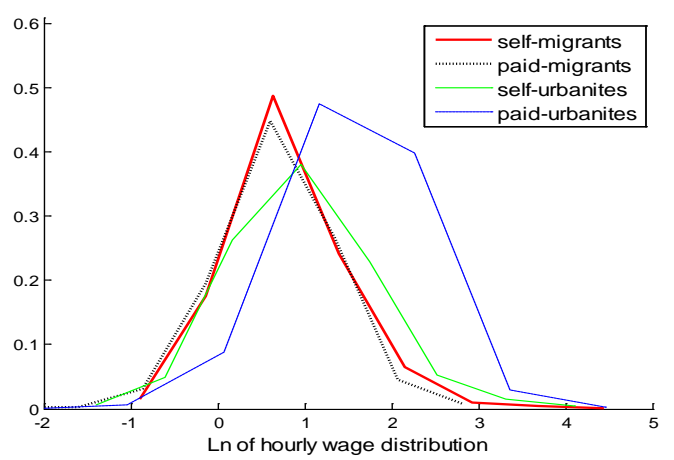


Table 6. Endogenous switching model wage estimates for rural migrant workers

\begin{tabular}{|c|c|c|c|c|}
\hline & \multirow{2}{*}{\multicolumn{2}{|c|}{$\begin{array}{c}\begin{array}{c}\text { Reduced-form probit of self- } \\
\text { employment (I) }\end{array} \\
\end{array}$}} & \multicolumn{2}{|c|}{ Log hourly wage } \\
\hline & & & \multirow{2}{*}{$\begin{array}{l}\text { Self-employed (II) } \\
\text { Coefficient }\end{array}$} & \multirow{2}{*}{$\begin{array}{l}\text { Paid-employed (III) } \\
\text { Coefficient }\end{array}$} \\
\hline \multirow{3}{*}{ City work experience } & Coefficient & Marginal effect & & \\
\hline & $0.1034 * * *$ & $0.0412 * * *$ & $0.0766^{* * *}$ & $0.0864 * * *$ \\
\hline & $(0.0238)$ & $(0.0095)$ & $(0.0176)$ & $(0.0175)$ \\
\hline \multirow[t]{2}{*}{ City work experience ${ }^{\wedge} 2$} & $-0.0049 * * *$ & $-0.0020 * * *$ & $-0.0033^{* * *}$ & $-0.0035 * * *$ \\
\hline & $(0.0015)$ & $(0.0006)$ & $(0.0011)$ & $(0.0011)$ \\
\hline \multirow[t]{2}{*}{ Vocational training } & $0.0329 * * *$ & $0.0131 * * *$ & $0.0160 * *$ & $0.0403^{* * *}$ \\
\hline & $(0.0122)$ & $(0.0049)$ & $(0.0086)$ & $(0.0088)$ \\
\hline \multirow[t]{2}{*}{ Married } & $0.6188^{* * *}$ & $0.2380 * * *$ & $0.2214^{* *}$ & $0.4515^{* * *}$ \\
\hline & $(0.0997)$ & $(0.0350)$ & $(0.0923)$ & $(0.0673)$ \\
\hline \multirow[t]{2}{*}{ Ethnic minority } & 0.0565 & 0.0216 & -0.0597 & $0.1044^{*}$ \\
\hline & $(0.0997)$ & $(0.0354)$ & $(0.0638)$ & $(0.0620)$ \\
\hline \multirow[t]{2}{*}{ Members of CPC } & -0.1161 & -0.0448 & 0.0530 & -0.0316 \\
\hline & $(0.1435)$ & $(0.0568)$ & $(0.1024)$ & $(0.0954)$ \\
\hline \multirow[t]{2}{*}{ Household size } & $0.0782 * *$ & $0.0328 * *$ & $0.1029 * * *$ & $0.0544^{* *}$ \\
\hline & $(0.0355)$ & $(0.0141)$ & $(0.0235)$ & $(0.0260)$ \\
\hline \multirow[t]{2}{*}{ Health } & $0.1850 * *$ & $0.0713^{* *}$ & $0.2021^{* * *}$ & $0.3225 * * *$ \\
\hline & $(0.0925)$ & $(0.0365)$ & $(0.0684)$ & $(0.0648)$ \\
\hline \multicolumn{5}{|c|}{ Education (reference: preliminary and below) } \\
\hline \multirow[t]{2}{*}{ Junior } & 0.0390 & 0.0179 & $0.1798 * * *$ & $0.17245^{* * *}$ \\
\hline & $(0.0593)$ & $(0.0236)$ & $(0.0391)$ & $(0.0420)$ \\
\hline \multirow[t]{2}{*}{ Senior } & 0.0468 & 0.0183 & $0.3134 * * *$ & $0.3445^{* * *}$ \\
\hline & $(0.0812)$ & $(0.0323)$ & $(0.0542)$ & $(0.0551)$ \\
\hline \multirow[t]{2}{*}{ College and above } & -0.0389 & -0.0168 & $0.3746 * *$ & $0.5281 * * *$ \\
\hline & $(0.2065)$ & $(0.0824)$ & $(0.1618)$ & $(0.1208)$ \\
\hline \multicolumn{5}{|c|}{ Industry dummies (reference: Wholesale/retail/food services) } \\
\hline Manufacturing \& Construction & $-0.8694 * * *$ & $-0.3242 * * *$ & $0.1396 *$ & $-0.2277 * * *$ \\
\hline & $(0.0758)$ & $(0.0247)$ & $(0.0799)$ & $(0.0747)$ \\
\hline Social services & $-0.9956 * * *$ & $-0.3710^{* * *}$ & $-0.2465 * * *$ & $-0.5057 * * *$ \\
\hline & $(0.0637)$ & $(0.0211)$ & $(0.0755)$ & $(0.0712)$ \\
\hline ILEP/other & $-1.1045^{* * *}$ & $-0.3938 * * *$ & 0.0225 & $-0.4517 * * *$ \\
\hline & $(0.0809)$ & $(0.0226)$ & $(0.0908)$ & $(0.0824)$ \\
\hline Receiving areas (reference: Beij & & & & \\
\hline Shanxi & $0.2842 * *$ & $0.1124^{* *}$ & $-0.2567 * *$ & $-0.1839 *$ \\
\hline & $(0.1470)$ & $(0.0562)$ & $(0.1116)$ & (0.0993) \\
\hline Liaoning & -0.1112 & -0.0436 & $-0.2264 * *$ & $-0.739 * *$ \\
\hline & $(0.1285)$ & $(0.0512)$ & $(0.0968)$ & $(0.0863)$ \\
\hline Jiangsu & 0.0246 & 0.0123 & 0.0428 & -0.1134 \\
\hline & $(0.1300)$ & $(0.0517)$ & $(0.0981)$ & $(0.0859)$ \\
\hline Anhui & $0.4883 * * *$ & $0.1893^{* * *}$ & $-0.3153^{* * *}$ & 0.0502 \\
\hline & $(0.1322)$ & $(0.0478)$ & $(0.0976)$ & $(0.0969)$ \\
\hline Henan & $0.6062 * * *$ & $0.2355^{* * *}$ & $-0.1991 * *$ & -0.1151 \\
\hline & $(0.1313)$ & $(0.0449)$ & $(0.0977)$ & $(0.0966)$ \\
\hline Hubei & $0.2585 * *$ & $0.1018 * *$ & $-0.2531 * * *$ & -0.1481 \\
\hline & $(0.1324)$ & $(0.0511)$ & $(0.0966)$ & $(0.0931)$ \\
\hline Guangdong & 0.0180 & 0.0105 & 0.0612 & 0.0486 \\
\hline & (0.1283) & $(0.0511)$ & $(0.0969)$ & $(0.0850)$ \\
\hline Sichuan & $0.4148 * * *$ & $0.1662 * * *$ & $-0.2915^{* * *}$ & -0.1418 \\
\hline & $(0.1338)$ & $(0.0492)$ & $(0.0990)$ & $(0.0972)$ \\
\hline Yunnan & 0.0232 & 0.0115 & $-0.2536 * *$ & $-0.2486 * * *$ \\
\hline & $(0.1377)$ & $(0.0548)$ & $(0.1030)$ & $(0.0923)$ \\
\hline Gansu & -0.0606 & -0.0227 & $-0.3300 * * *$ & $-0.5498 * * *$ \\
\hline & $(0.1414)$ & $(0.0564)$ & $(0.1058)$ & $(0.0943)$ \\
\hline Occupation before migration (re & rence: agricu & re) & & \\
\hline Work in enterprises & $0.1245^{*}$ & $0.0494 *$ & & \\
\hline & $(0.0727)$ & $(0.0288)$ & & \\
\hline The educated & $-0.2098 * * *$ & $-0.0830 * * *$ & & \\
\hline
\end{tabular}




\begin{tabular}{|c|c|c|c|c|}
\hline & $(0.0727)$ & $(0.0287)$ & & \\
\hline \multirow[t]{2}{*}{ Unemployment duration } & $-0.0248 *$ & $-0.0096^{*}$ & & \\
\hline & $(0.0143)$ & $(0.0057)$ & & \\
\hline \multirow[t]{2}{*}{ Money brought from family } & $0.0001 * * *$ & 7.37e-06*** & & \\
\hline & (3.53e-06) & $(0.0000)$ & & \\
\hline \multirow[t]{2}{*}{ Hours/month } & $0.0036 * * *$ & $0.0014^{* * *}$ & & \\
\hline & $(0.0003)$ & $(0.0001)$ & & \\
\hline \multirow[t]{2}{*}{ Constant } & $-1.9173 * * *$ & & $-0.4613^{* *}$ & $0.2707 * *$ \\
\hline & $(0.2295)$ & & $(0.2045)$ & $(0.1364)$ \\
\hline \multirow[t]{2}{*}{ Selectivity term } & & & $0.4909 * * *$ & $-0.7774 * * *$ \\
\hline & & & $(0.0992)$ & $(0.0901)$ \\
\hline Observations & & 080 & 1,569 & 1,511 \\
\hline Wald $x^{2}$ & & & 260.82 & \\
\hline $\mathrm{p}$ & & & 0.0000 & \\
\hline
\end{tabular}

Notes: Standard errors in parentheses. ${ }^{*} \mathrm{p}<0.1$; ${ }^{* *} \mathrm{p}<0.05$; ${ }^{* * *} \mathrm{p}<0.01$. 
Table 7. Endogenous switching model wage estimates for urban residents

\begin{tabular}{|c|c|c|c|c|}
\hline & \multirow{2}{*}{\multicolumn{2}{|c|}{$\begin{array}{l}\text { Reduced-form probit of self- } \\
\text { employment (I) }\end{array}$}} & \multicolumn{2}{|c|}{$\begin{array}{c}\text { Log hourly wage } \\
\end{array}$} \\
\hline & & & \multirow{2}{*}{$\begin{array}{l}\text { Self-employed (II) } \\
\text { Coefficient }\end{array}$} & \multirow{2}{*}{$\begin{array}{l}\text { Paid-employed (III) } \\
\text { Coefficient }\end{array}$} \\
\hline \multirow{3}{*}{ City work experience } & Coefficient & Marginal effect & & \\
\hline & -0.0083 & -0.0003 & $0.0350 * *$ & 0.0110 \\
\hline & $(0.0164)$ & $(0.0006)$ & $(0.0185)$ & $(0.0101)$ \\
\hline \multirow[t]{2}{*}{ City work experience ${ }^{\wedge} 2$} & -0.0001 & $-4.35 e-06$ & $-0.0009 * *$ & -0.00002 \\
\hline & $(0.0004)$ & $(0.00002)$ & $(0.0005)$ & $(0.0002)$ \\
\hline \multirow[t]{2}{*}{ Vocational training } & -0.0053 & -0.0003 & $0.0450 * *$ & $0.0218^{* *}$ \\
\hline & $(0.0199)$ & $(0.0008)$ & $(0.0241)$ & $(0.0099)$ \\
\hline \multirow[t]{2}{*}{ Married } & $0.7768 * * *$ & $0.0159 * * *$ & 0.2389 & $0.2647^{* * *}$ \\
\hline & $(0.1557)$ & $(0.0021)$ & $(0.1884)$ & $(0.0821)$ \\
\hline \multirow[t]{2}{*}{ Ethnic minority } & $0.4966^{* * *}$ & $0.0305^{* * *}$ & 0.1079 & 0.1391 \\
\hline & $(0.1311)$ & $(0.0121)$ & $(0.1490)$ & $(0.0948)$ \\
\hline \multirow[t]{2}{*}{ Members of CPC } & $-0.1935^{* *}$ & $-0.0062 * *$ & $-0.3043^{* *}$ & $0.0727 * *$ \\
\hline & $(0.0919)$ & $(0.0029)$ & $(0.1229)$ & $(0.0422)$ \\
\hline \multirow[t]{2}{*}{ Household size } & 0.0031 & 0.0001 & -0.0708 & $-0.0698 * * *$ \\
\hline & $(0.0425)$ & $(0.0016)$ & $(0.0466)$ & $(0.0260)$ \\
\hline \multirow[t]{2}{*}{ Health } & $0.1435^{* *}$ & $0.0051 * *$ & $0.2682^{* * *}$ & $0.0679 *$ \\
\hline & $(0.0695)$ & $(0.0024)$ & $(0.0827)$ & $(0.0380)$ \\
\hline \multicolumn{5}{|c|}{ Education (reference: preliminary and below) } \\
\hline \multirow[t]{2}{*}{ Junior } & $-0.4896 * * *$ & $-0.0143^{* * *}$ & -0.1257 & 0.0741 \\
\hline & $(0.1309)$ & $(0.0032)$ & $(0.1330)$ & $(0.1204)$ \\
\hline \multirow[t]{2}{*}{ Senior } & $-0.6978 * * *$ & $-0.0243^{* * *}$ & -0.1545 & $0.2039 *$ \\
\hline & $(0.1328)$ & $(0.0051)$ & $(0.1415)$ & $(0.1209)$ \\
\hline \multirow[t]{2}{*}{ College and above } & $-0.9931 * * *$ & $-0.0305 * * *$ & 0.1884 & $0.4587 * * *$ \\
\hline & $(0.1531)$ & $(0.0048)$ & $(0.1898)$ & $(0.1253)$ \\
\hline \multicolumn{5}{|c|}{ Industry dummies (reference: Wholesale/retail/food services) } \\
\hline \multirow{2}{*}{ Manufacturing \& Construction } & $-1.0089 * * *$ & $-0.0274 * * *$ & $-0.3839 * * *$ & $-0.1411 * *$ \\
\hline & $(0.0943)$ & $(0.0029)$ & $(0.1505)$ & $(0.0705)$ \\
\hline Social services & $-0.6464 * * *$ & $-0.0222 * * *$ & $-0.3697 * * *$ & 0.0497 \\
\hline & $(0.0787)$ & $(0.0031)$ & $(0.0974)$ & $(0.0662)$ \\
\hline ILEP/other & $-0.6124 * * *$ & $-0.0161 * * *$ & -0.1676 & 0.0947 \\
\hline & $(0.0889)$ & $(0.0022)$ & $(0.1171)$ & $(0.0705)$ \\
\hline Receiving areas (reference: Be & jing) & & & \\
\hline Shanxi & 0.0105 & 0.0026 & $-0.7870 * * *$ & $-0.6188 * * *$ \\
\hline & $(0.1912)$ & $(0.0079)$ & $(0.2594)$ & $(0.0835)$ \\
\hline Liaoning & 0.1162 & 0.0048 & $-0.8905^{* * *}$ & $-0.5395^{* * *}$ \\
\hline & $(0.1692)$ & $(0.0077)$ & $(0.2350)$ & $(0.0744)$ \\
\hline Jiangsu & 0.1318 & 0.0057 & $-0.9605 * * *$ & $-0.3790 * * *$ \\
\hline & $(0.1723)$ & $(0.0081)$ & $(0.2406)$ & $(0.0756)$ \\
\hline Anhui & 0.1657 & 0.0072 & $-1.0436 * * *$ & $-0.5085^{* * *}$ \\
\hline & $(0.1822)$ & $(0.0092)$ & $(0.2468)$ & $(0.0847)$ \\
\hline Henan & $0.4092 * *$ & $0.0219 * *$ & $-0.8673 * * *$ & $-0.6573^{* * *}$ \\
\hline & $(0.1658)$ & $(0.0122)$ & $(0.2327)$ & $(0.0807)$ \\
\hline Hubei & -0.1834 & -0.0061 & $-1.1484 * * *$ & $-0.5518^{* * *}$ \\
\hline & $(0.1941)$ & $(0.0053)$ & $(0.2625)$ & $(0.0770)$ \\
\hline Guangdong & $0.4009 * *$ & $0.0212 * *$ & -0.2931 & 0.0962 \\
\hline & $(0.1674)$ & $(0.0120)$ & $(0.2393)$ & $(0.0782)$ \\
\hline Sichuan & 0.1175 & 0.0052 & $-1.2431 * * *$ & $-0.5534 * * *$ \\
\hline & $(0.1751)$ & $(0.0081)$ & $(0.2410)$ & $(0.0808)$ \\
\hline Yunnan & $0.3855 * *$ & $0.0208 * *$ & $-0.7512 * * *$ & $-0.4026 * * *$ \\
\hline & $(0.1778)$ & $(0.0130)$ & $(0.2472)$ & $(0.0867)$ \\
\hline Gansu & 0.2123 & 0.0095 & $-1.0679 * * *$ & $-0.6373 * * *$ \\
\hline & $(0.1826)$ & $(0.0100)$ & $(0.2473)$ & $(0.0880)$ \\
\hline Unemployment experience & $0.2942 * * *$ & $0.0136^{* * *}$ & & \\
\hline & $(0.0692)$ & $(0.0040)$ & & \\
\hline Hours/month & $0.0072^{* * *}$ & $0.0003^{* * *}$ & & \\
\hline & $(0.0005)$ & $(0.00003)$ & & \\
\hline
\end{tabular}




\begin{tabular}{|c|c|c|c|}
\hline Selectivity term & $\begin{array}{l}-2.9273^{* * *} \\
(0.3077)\end{array}$ & $\begin{array}{l}0.6589 * * \\
(0.3852) \\
0.6704^{* * *} \\
(0.0807) \\
\end{array}$ & $\begin{array}{l}1.5103^{* * *} \\
(0.1857) \\
-1.5220^{* * *} \\
(0.1460)\end{array}$ \\
\hline Observations & 8,081 & 373 & 7,708 \\
\hline Wald $x^{2}$ & & 130.04 & \\
\hline $\mathrm{p}$ & & 0.0000 & \\
\hline
\end{tabular}


Table 8. Structural probit estimation results: Probability of self-employment

\begin{tabular}{|c|c|c|c|c|c|}
\hline \multirow[b]{2}{*}{ Variables } & \multicolumn{2}{|c|}{ Rural migrants } & \multicolumn{2}{|c|}{ Urban residents } & \multirow{2}{*}{$\begin{array}{c}\text { Interactions } \\
\text { with the } \\
\text { dummy }(X D)\end{array}$} \\
\hline & $\begin{array}{l}\text { Coefficient } \\
\left(X_{r}\right)\end{array}$ & $\begin{array}{l}\text { Marginal } \\
\text { effect }\end{array}$ & $\begin{array}{l}\text { Coefficient } \\
\left(X_{u}\right)\end{array}$ & $\begin{array}{l}\text { Marginal } \\
\text { effect }\end{array}$ & \\
\hline \multirow[t]{2}{*}{ Difference in log predicted earnings } & $0.1978 * * *$ & $0.0789 * * *$ & 0.0250 & 0.0009 & $0.1728 * * *$ \\
\hline & $(0.0567)$ & $(0.0226)$ & $(0.0159)$ & $(0.0006)$ & $(0.0588)$ \\
\hline \multirow[t]{2}{*}{ Vocational training } & $0.0307 * *$ & $0.0122 * *$ & -0.0073 & -0.0003 & $0.0380 * *$ \\
\hline & $(0.0124)$ & $(0.0049)$ & $(0.0202)$ & $(0.0007)$ & $(0.0237)$ \\
\hline \multirow[t]{2}{*}{ Married } & $0.5489 * * *$ & $0.2124 * * *$ & $0.6022 * * *$ & $0.0136 * * *$ & -0.0533 \\
\hline & $(0.1074)$ & $(0.0388)$ & $(0.1342)$ & $(0.0021)$ & $(0.1719)$ \\
\hline \multirow[t]{2}{*}{ Ethnic minority } & 0.0726 & 0.0289 & $0.4422 * * *$ & $0.0252 * *$ & $-0.3695 * *$ \\
\hline & $(0.0890)$ & $(0.0353)$ & $(0.1333)$ & $(0.0111)$ & $(0.1603)$ \\
\hline \multirow[t]{2}{*}{ Members of CPC } & -0.1018 & -0.0406 & $-0.1831 * *$ & $-0.0061^{* *}$ & 0.0813 \\
\hline & $(0.1439)$ & $(0.0573)$ & $(0.0957)$ & $(0.0030)$ & $(0.1728)$ \\
\hline \multirow[t]{2}{*}{ Household size } & 0.0565 & 0.0225 & 0.0134 & 0.0005 & 0.0431 \\
\hline & $(0.0377)$ & $(0.0151)$ & $(0.0422)$ & $(0.0015)$ & $(0.0566)$ \\
\hline \multirow[t]{2}{*}{ Health } & $0.1337 * *$ & $0.0533 * *$ & $0.1549 * *$ & $0.0053^{* *}$ & -0.0212 \\
\hline & $(0.0920)$ & $(0.0366)$ & $(0.0694)$ & $(0.0023)$ & $(0.1152)$ \\
\hline \multicolumn{6}{|c|}{ Education (reference: preliminary and below) } \\
\hline \multirow[t]{2}{*}{ Junior } & 0.0317 & 0.0126 & $-0.4085 * * *$ & $-0.0119 * * *$ & $0.4402^{* * *}$ \\
\hline & $(0.0591)$ & $(0.0236)$ & $(0.1312)$ & $(0.0034)$ & $(0.1439)$ \\
\hline \multirow[t]{2}{*}{ Senior } & 0.0445 & 0.0178 & $-0.5634 * * *$ & $-0.0193 * * *$ & $0.6080^{* * *}$ \\
\hline & $(0.0811)$ & $(0.0323)$ & $(0.1350)$ & $(0.0050)$ & $(0.1575)$ \\
\hline \multirow[t]{2}{*}{ College and above } & 0.0972 & 0.0386 & $-0.7462 * * *$ & $-0.0226 * * *$ & $0.8434 * * *$ \\
\hline & $(0.2144)$ & $(0.0849)$ & $(0.1743)$ & $(0.0053)$ & $(0.2763)$ \\
\hline \multicolumn{6}{|c|}{ Industry dummies (reference: Wholesale/retail/food services) } \\
\hline \multirow[t]{2}{*}{ Manufacturing \& Construction } & $-0.5386 * * *$ & $-0.2097 * * *$ & $-0.9245 * * *$ & $-0.0249 * * *$ & $0.3859 * *$ \\
\hline & $(0.1143)$ & $(0.0422)$ & $(0.1082)$ & $(0.0034)$ & $(0.1574)$ \\
\hline \multirow[t]{2}{*}{ Social services } & $-0.6424 * * *$ & $-0.2500 * * *$ & $-0.5849 * * *$ & $-0.0194 * * *$ & -0.0574 \\
\hline & $(0.1127)$ & $(0.0416)$ & $(0.0915)$ & $(0.0036)$ & $(0.1452)$ \\
\hline ILEP/other & $-0.7447 * * *$ & $-0.2821 * * *$ & $-0.5466 * * *$ & $-0.0145 * * *$ & -0.1981 \\
\hline & $(0.1291)$ & $(0.0438)$ & $(0.0986)$ & $(0.0025)$ & $(0.1625)$ \\
\hline Receiving areas (reference: Beijing) & & & & & \\
\hline Shanxi & 0.1235 & 0.0491 & -0.0218 & -0.0008 & 0.1452 \\
\hline & $(0.1522)$ & $(0.0601)$ & $(0.2065)$ & $(0.0072)$ & $(0.2566)$ \\
\hline Liaoning & -0.1110 & -0.0442 & 0.0219 & 0.0008 & -0.1328 \\
\hline & $(0.1292)$ & $(0.0515)$ & (0.1899) & $(0.0072)$ & $(0.2297)$ \\
\hline Jiangsu & -0.0502 & -0.0200 & 0.0598 & 0.0023 & -0.1100 \\
\hline & $(0.1321)$ & (0.0527) & (0.1889) & $(0.0076)$ & $(0.2305)$ \\
\hline Anhui & $0.3195 * *$ & $0.1254^{* *}$ & 0.0726 & 0.0023 & 0.2470 \\
\hline & $(0.1376)$ & $(0.0527)$ & (0.1999) & $(0.0083)$ & $(0.2427)$ \\
\hline Henan & $0.3437 * *$ & $0.1346^{* *}$ & 0.2919 & 0.0138 & 0.0518 \\
\hline & $(0.1489)$ & $(0.0567)$ & $(0.1984)$ & $(0.0121)$ & $(0.2481)$ \\
\hline Hubei & 0.1485 & 0.0590 & -0.2393 & -0.0071 & 0.3878 \\
\hline & $(0.1368)$ & $(0.0540)$ & $(0.2054)$ & $(0.0049)$ & $(0.2468)$ \\
\hline Guangdong & -0.0013 & -0.0005 & $0.3229 * * *$ & $0.0157 * * *$ & -0.3242 \\
\hline & $(0.1292)$ & $(0.0515)$ & $(0.1819)$ & $(0.0115)$ & $(0.2231)$ \\
\hline Sichuan & $0.2719 * *$ & $0.1071^{* *}$ & 0.0424 & 0.0016 & 0.2295 \\
\hline & $(0.1404)$ & $(0.0542)$ & $(0.1939)$ & $(0.0076)$ & $(0.2394)$ \\
\hline Yunnan & -0.0451 & -0.0180 & 0.2938 & 0.0141 & -0.3389 \\
\hline & $(0.1375)$ & $(0.0548)$ & $(0.2035)$ & $(0.0126)$ & $(0.2456)$ \\
\hline Gansu & -0.1574 & -0.0627 & 0.1073 & 0.0043 & -0.2646 \\
\hline & $(0.1420)$ & $(0.0563)$ & $(0.2056)$ & $(0.0092)$ & $(0.2499)$ \\
\hline Unemployment duration & -0.0157 & -0.0063 & & & \\
\hline & $(0.0145)$ & $(0.0058)$ & & & \\
\hline Occupation before migration (refere & e: agricultuı & & & & \\
\hline Work in enterprises & 0.0492 & 0.0196 & & & \\
\hline & $(0.0738)$ & $(0.0294)$ & & & \\
\hline The educated & -0.1013 & -0.0404 & & & \\
\hline
\end{tabular}


Money brought from family

(0.0774) (0.0309)

$0.0001^{* * *} \quad 4.67 \mathrm{e}-06^{* * *}$

$(3.84 \mathrm{e}-06) \quad(0.0000)$

Hours/month

$0.0021^{* * *} \quad 0.0008^{* * *}$

$(0.0005)$

$(0.0002)$

Unemployment experience

\section{Constant}

$-1.0559 * * *$

(0.2848)

Log likelihood
Observations

-1702.5098
3,080

Pseudo $R^{2}$

0.2023

\begin{tabular}{lll}
$0.0068 * * *$ & $0.0002 * * *$ & $-0.0047 * * *$ \\
$(0.0006)$ & $(0.00003)$ & $(0.0008)$ \\
$0.2597 * * *$ & $0.0115^{* * *}$ & \\
$(0.0712)$ & $(0.0039)$ & \\
$-2.8817^{* * *}$ & & $1.8259 * * *$ \\
$(0.3567)$ & & $(0.4565)$ \\
\hline \multicolumn{2}{r}{-1008.4151} & -2710.925 \\
8,081 & 1,1161 \\
0.3381 & 0.4751
\end{tabular}

Notes: Standard errors in parentheses. ${ }^{*} \mathrm{p}<0.1$; $^{* *} \mathrm{p}<0.05$; ${ }^{* * *} \mathrm{p}<0.01$.

Table 9. Results of joint hypothesis test

\begin{tabular}{r|l}
\hline Explanatory variables & \multicolumn{1}{c}{ Likelihood-ratio test } \\
\hline Education & $\begin{array}{l}\text { Ho: The coefficients of each category in education dummy are the same. } \\
\text { Chi2 }(3)=16.62, \text { Prob }>\text { chi2 }=0.0008\end{array}$ \\
\hline Industry & $\begin{array}{l}\text { Ho: The coefficients of each category in industry dummy are the same. } \\
\text { Chi2 }(3)=19.29, \text { Prob }>\text { chi2 }=0.0002\end{array}$ \\
\hline Region & $\begin{array}{l}\text { Ho: The coefficients of each category in region dummy are the same. } \\
\text { Chi2 }(10)=29.16, \text { Prob }>\text { chi2 }=0.0012\end{array}$ \\
\hline
\end{tabular}


Table 10. Blinder-Oaxaca decomposition of log wage differential

\begin{tabular}{|c|c|c|}
\hline & \multicolumn{2}{|c|}{$\begin{array}{l}\text { Self-employed migrants vs. } \\
\text { paid-employed migrants } \\
\text { (Paid-employed as base) }\end{array}$} \\
\hline \multicolumn{3}{|l|}{ Wage differential after correction for sample selection bias } \\
\hline The mean of log self-employed migrants & \multicolumn{2}{|c|}{0.7745} \\
\hline The mean of log paid-employed migrants & \multicolumn{2}{|c|}{0.6909} \\
\hline Total difference & \multicolumn{2}{|c|}{0.0836} \\
\hline & Value & Portion (\%) \\
\hline Endowment differences & -0.0309 & -11.69 \\
\hline Coefficient differences & 0.2049 & 77.50 \\
\hline \multirow[t]{2}{*}{ Interaction term } & 0.0904 & 34.19 \\
\hline & \multicolumn{2}{|c|}{$\begin{array}{l}\text { Self-employed urbanites vs. } \\
\text { paid-employed urbanites } \\
\text { (Paid-employed as base) }\end{array}$} \\
\hline \multicolumn{3}{|l|}{ Wage differential after correction for sample selection bias } \\
\hline The mean of log self-employed urbanites & \multicolumn{2}{|c|}{0.9917} \\
\hline The mean of log paid-employed urbanites & \multicolumn{2}{|c|}{1.5556} \\
\hline Total difference & \multicolumn{2}{|c|}{-0.5640} \\
\hline & Value & Portion (\%) \\
\hline Endowment differences & -0.3588 & -63.63 \\
\hline Coefficient differences & -0.1780 & -31.57 \\
\hline \multirow[t]{2}{*}{ Interaction term } & -0.0271 & -4.81 \\
\hline & \multicolumn{2}{|c|}{$\begin{array}{l}\text { Self-employed urbanites vs. } \\
\text { self-employed migrants } \\
\text { (Self-employed migrants as base) }\end{array}$} \\
\hline \multicolumn{3}{|l|}{ Wage differential after correction for sample selection bias } \\
\hline The mean of log self-employed urbanites & \multicolumn{2}{|c|}{0.9917} \\
\hline The mean of log self-employed migrants & \multicolumn{2}{|c|}{0.7745} \\
\hline Total difference & \multicolumn{2}{|c|}{0.2172} \\
\hline & Value & Portion (\%) \\
\hline Endowment differences & 0.0560 & 25.79 \\
\hline Coefficient differences & 0.0822 & 37.85 \\
\hline \multirow[t]{2}{*}{ Interaction term } & 0.0790 & 36.37 \\
\hline & \multicolumn{2}{|c|}{$\begin{array}{l}\text { Paid-employed urbanites vs. } \\
\text { paid-employed migrants } \\
\text { (Paid-employed migrants as base) }\end{array}$} \\
\hline \multicolumn{3}{|l|}{ Wage differential after correction for sample selection bias } \\
\hline The mean of log paid-employed urbanites & \multicolumn{2}{|c|}{1.5556} \\
\hline The mean of log paid-employed migrants & \multicolumn{2}{|c|}{0.6909} \\
\hline Total difference & \multicolumn{2}{|c|}{0.8647} \\
\hline & Value & Portion (\%) \\
\hline Endowment differences & 0.3332 & 38.53 \\
\hline Coefficient differences & 0.3756 & 43.44 \\
\hline Interaction term & 0.1559 & 18.03 \\
\hline
\end{tabular}

